\title{
Is there a 'European' corporate criminology? Introduction to the Special Issue on European corporate crime
}

European Journal of Criminology 2020, Vol. I7(I) 3-8

(C) The Author(s) 2019

Article reuse guidelines: sagepub.com/journals-permissions DOI: I0.1 I77/I4773708/9889|63 journals.sagepub.com/home/euc

@SAGE

\section{Judith Van Erp}

Utrecht University, The Netherlands

\section{Nicholas Lord}

University of Manchester, UK

In 2015, it was revealed how software manipulation and emissions fraud were deeply embedded in one of the most iconic European companies, Volkswagen (VW), as well as in several other European car manufacturers (Ewing, 2017). In addition to confirming concerns about the lenient EU regulation of diesel emissions, the discovery of the fraud in the US painfully illustrated the complete absence of enforcement in the European car manufacturing industry as compared with the US. Moreover, the VW fraud provides a perfect illustration of strain (Agnew, 1992), as Volkswagen did not have the technical ability to manufacture a 'clean' diesel engine that was at the same time attractive enough to survive in a competitive global market.

The VW diesel fraud is only one example of European corporate crimes that raises questions about the relationship between the globalization of markets and corporate crime in Europe (Braithwaite and Drahos, 2000). In the case of Volkswagen, globalization seems to have played a role both in the commission of crimes - because increased global competition provided a motive to deceive consumers and regulators - as well as in its detection - it was enforcement by the US Environmental Protection Agency that brought the fraud to the light and led to inquiries in Europe as well.

\section{Corresponding author:}

Judith Van Erp, Utrecht School of Governance, Utrecht University, Bijlhouwerstraat 6, Utrecht, 35I I ZC, Netherlands.

Email: j.g.vanerp@uu.nl 
Other recent cases suggest different causal paths. Creative tax compliance by US companies such as Starbucks and Apple, headquartered in EU countries, suggests that European governments are willing to offer sweetheart deals to US companies. Here, EU member states withstand EU legislation on state aid and reveal how what is interpreted as illegal in Brussels is viewed as beneficial by the Irish, Dutch and UK governments. Criminologists have long since found such legal and moral ambiguities conducive to corporate behaviour that benefits from legal loopholes and a lack of societal condemnation (Pearce, 1976; Passas,, 1990; Nelken 2012; Pontell et al., 2014; Whyte, 2014). This may be expected to increase should Brexit and increased competition from the UK for international business occur.

As a third example, the 2013 horsemeat and 2018 Fipronil egg food scandals reveal how European common markets create transnational risk as contaminated food products travel within the common market. Here, open borders between EU states create opportunities for exchange between European businesses, but, with coordination problems in enforcement, risk in one country can rapidly spread in other European states. This problem is not unique for food production: the common market also allows for the free flow of labour, offering businesses in north-west Europe the opportunity to import cheap labour from the European east and south, creating openings for the exploitation of cheap labour and the avoidance of social benefits and endangering the promise of a prosperous and equal social market economy in the EU.

As these examples show, business crime creates enormous financial damage to individuals, market legitimacy and the economies of European states (Clinard and Yeager, 1980; Sutherland, 1949). In addition to financial, physical and environmental damage, it undermines citizens' trust in economic and political institutions. Criminological research into corporate and white-collar crimes has amply demonstrated that the business organization creates opportunities for illegitimate profits that stretch far beyond the opportunities for individual fraud or crime (Benson and Simpson, 2015; Pearce, 1976; Punch, 2000; Sutherland, 1949; Van Rooij and Fine, 2018). These opportunities are connected to underlying European principles of 'open societies' and the development of an area of freedom, security and justice in various ways: the complexity and lack of transparency of modern markets and production/distribution networks; the use of technology; the increasing transnational character of business; the geographical dispersal of the production and consumption of goods; and the separation between individual and corporate legal liability and societal responsibility. However, current scholarship on corporate, organizational and white-collar crime is theoretically underdeveloped, in particular in comparison with theories on organized crime and street crime (Almond and Van Erp, 2019). Moreover, it is primarily focused on the US context, which makes theories less relevant for European states (Barak, 2015; Friedrichs, 2015; Van Erp et al., 2015). The above examples nevertheless suggest that Europe offers regulatory, market and politicaleconomic conditions that are partially distinct from US (and other) contexts, demanding for theoretical explanations tailored to these circumstances (for example, Etienne, 2015; Barak, 2015).

Aside from this, 'Europe' offers an arsenal of rich case studies - the Banco Espírito Santo scandal in Portugal, the Siemens corruption cases in Germany and Greece (Klinkhammer, 2015), the Libor and Euribor interest rate frauds, the Danske bank 
scandal - some of which are perhaps less known to international audiences but offer more vivid illustrations of the causes, harms and structures of corporate crimes to a European audience of practitioners, legislators and students. European criminologists have long taught corporate crime based on US cases (Geis, 1995; Friedrichs, 2004), which may raise questions with regard to European manifestations.

With this in mind, this Special Issue aims to bring European scholarship to the forefront of academic dialogue on corporate, organizational and white-collar crime and to reinforce the rich value that the diverse European region offers in terms of theory building. How we understand organizational crimes in relation to these regional European dynamics is a central theme within this Special Issue. A criminological lens allows us to understand the ambiguities surrounding corporate crimes provided by lenient national regulatory cultures and enforcement, the transition of European economies from corporatist and state-led to neoliberal capitalism, the position of 'old' industries in global markets, and collusive relations between industries and politicians conducive to crime. Some of these explanations may be universal, but they materialize in different forms in different political economies. (Mainstream) criminological and sociolegal scholarship on transatlantic differences in penal culture (Kagan, 2001; Garland, 2001) or regulation (Vogel, 2012) has shown how applying a geographical lens can be theoretically fruitful.

Analysis of what we now refer to as white-collar and corporate crime has a long history in Europe, with an early contribution from Bonger (1916; see also Van Erp et al., 2015) foregrounding how opportunities for elite offending (as for 'lower class' crime) are a product of the capitalist economic production regime. In more recent times, Europe has seen the emergence of the European Working Group on Organizational Crime (EUROC). Since its inception in 2010, EUROC has furthered the agenda of corporate crime scholarship in Europe, developing into a vibrant and intellectually sophisticated cross-European group of scholars working and researching in the areas of white-collar, corporate, organizational, occupational, financial and economic crimes, as well as their connections to 'organized crime' and other forms of illicit enterprise. EUROC's membership consists of continental European scholars from the north, south, east and west, as well as scholars from outside of Europe. The significance of this emerging research group is evidenced by the production of the Routledge Handbook of White-Collar and Corporate Crime in Europe, edited by Van Erp, Huisman and Vande Walle (2015) and the growing popularity of, and participation in, the Group's organized panels at the Annual Conference of the European Society of Criminology (ESC).

The articles in this Special Issue formed part of EUROC's first standalone workshop that took place outside of the ESC Annual Meeting in August 2017. The workshop showcased current scholarship on corporate and white-collar crime and provided a venue for scholars to present their research, strengthen their network, and shape future research across the social sciences via theoretically informed, methodologically rigorous empirical work. With the workshop, we sought to motivate corporate and white-collar crime scholars to advance theoretical insights and use appropriate empirical methods and data in order to ensure a high level of intellectual and methodological rigour and to provide an avenue for intensive and high-quality interactions and dialogue.

Given the diversity of European jurisdictions, there is rich soil for the development of theory and concepts on white-collar and corporate crimes, and there is much that can be 
learned from the richness of European cases that often transcend the boundaries of individual nation-states within, and beyond, Europe. In these terms, intellectual development through cross-cultural empirical collaboration in Europe presents scope for developing a coordinated European dialogue that can inform global theoretical debates, but only if European criminologists and social scientists are able to talk with each other on European social issues, rather than past one another by remaining narrowly focused on individual nation-states or local case studies as the primary unit of analysis.

With the above in mind, this Special Issue includes six articles that analyse the organizational dynamics of corporate crimes in Europe. Across these articles we see different theoretical frameworks and methodological strategies implemented, reinforcing the intellectual diversity that exists within Europe. Commonalities exist in terms of the attention directed towards the need for multi-level and multi-mode analyses of corporate crimes to build fuller explanatory accounts, as we gain insights into the motivations of individual offenders as shaped by their organizational environments and underpinned by structural factors such as political-economic conditions.

Jordanoska and Lord present a script analysis of the Libor scandal to inform readers of the inherent procedural mechanics of the case and insight into cross-institutional collaborations by networks of implicated actors in the context of broader regulatory failures. Their empirical analysis demonstrates that regulatory and organizational systems play a paradoxical role of both 'capable guardians' and 'facilitators of misconduct', which in turn has implications for criminological theory beyond their case study.

Györy analyses the greatest Hungarian securities fraud to date: the Quaestor scandal. Györy foregrounds the political economy of Hungarian finance and the distortion of the regulatory regime through an emerging form of crony capitalism in Hungary as factors germane to how and why the case happened, before considering differences in the form and nature of financial crime in developing and developed economies.

The article by Peeters et al. investigates how several variables, more specifically industry conduct, company culture and personal motives, influence rule violations by companies. Their results show that ethical culture contributes to explaining the compliant intentions of both directors and employees but that about half of the companies cannot be characterized by a coherent ethical culture, because directors' and employees' perceived ethical business cultures substantially differ.

Davies discusses the ways in which labour exploitation is embedded in food supply networks and the corporate harms that this generates. The article draws attention to how such exploitation is routinized, embedded and normalized within otherwise legitimate business processes and that there are underlying structural issues and dysfunctionalities in the food system that are conducive to such corporate harm.

McGrath examines the Irish banking sector, drawing attention to the generative conditions that gave rise to the commission of irresponsible risk-taking. More specifically, McGrath analyses the micro-level influences, utilizing differential association theory and opportunity theory to demonstrate how, at both the individual and the group level, ideas, beliefs, expectations, rewards and punishments had a causal impact on banking culture, where competitive and aggressive risk-taking was prioritized, networked and routinized. 
Finally, Jaspers discusses the modus operandi of cartelists in keeping cartels secret. As his paper demonstrates, cooperation against the law requires extensive coordinative arrangements, which are facilitated by cartelists' embeddedness within their social environment. Jaspers provides a critical analysis of the leniency arrangements which, despite being the most important detection instrument in the EU's cartel enforcement as well as in member states, are unable to pierce through the strategic operations of cartels.

\section{Acknowledgements}

We thank both Utrecht University and Manchester University for their support and also thank the participants in this workshop for their suggestions and discussions.

\section{Funding}

The author(s) disclosed receipt of the following financial support for the research, authorship, and/ or publication of this article: This Special Issue is the result of a workshop sponsored by Utrecht University's School of Governance, Utrecht University's strategic theme 'Institutions for Open Societies' and Manchester University's School of Law.

\section{References}

Almond P and Van Erp J (2019) Regulation and governance versus criminology: Disciplinary divides, intersections, and opportunities. Regulation \& Governance.

Agnew R (1992) Foundation for a general strain theory of crime and delinquency. Criminology 30(1): 47-88.

Barak G (2015) The Routledge International Handbook of the Crimes of the Powerful. London: Routledge.

Benson M and Simpson S (2015) Understanding White Collar Crime, an Opportunity Perspective. Abingdon: Routledge.

Braithwaite J and Drahos P (2000) Global Business Regulation. Cambridge: Cambridge University Press.

Clinard MB and Yeager PC (1980) Corporate Crime. New Brunswick, NJ: Transaction Press.

Etienne J (2015) Different ways of blowing the whistle: Explaining variations in decentralized enforcement in the UK and France. Regulation \& Governance 9(4): 309-324.

Ewing J (2017) Faster, Higher, Farther. The Volkswagen Scandal. New York: Norton \& Co.

Friedrichs D (2004) Enron et al.: Paradigmatic white collar crime cases for the new century. Critical Criminology 12: 113.

Friedrichs DO (2015) White-collar crime in Europe: American reflections. In: Van Erp J, Huisman W and Vande Walle G (eds) The Routledge Handbook of White-Collar and Corporate Crime in Europe. Abingdon: Routledge, 548-560.

Garland D (2001) The Culture of Control. Crime and Social Order in Contemporary Society. Oxford: Oxford University Press.

Geis G, Meier F and Salinger L (1995), White Collar Crime: Classic and Contemporary Views, 3rd edition. New York: Free Press.

Kagan RA (2001) Adversarial Legalism, the American Way of Law. Cambridge, MA: Harvard University Press.

Klinkhammer J (2015) Varieties of corruption in the shadow of Siemens: A modus operandi study of corporate crime on the supply side of corrupt transactions. In: Van Erp J, Huisman W and Vande Walle G (eds) The Routledge Handbook of White-Collar and Corporate Crime in Europe. Abingdon: Routledge, 318-336. 
Nelken D (2012) White collar and corporate crime. In: Maguire M, Morgan R and Reiner R (eds) The Oxford Handbook of Criminology. Oxford: Oxford University Press, 623-659.

Passas N (1990) Anomie and corporate deviance. Contemporary Crises 14(2): 157-178.

Pearce F (1976) Crimes of the Powerful: Marxism, Crime and Deviance. London: Pluto Press.

Pontell HN, Black WK and Geis G (2014) Too big to fail, too powerful to jail? On the absence of criminal prosecutions after the 2008 financial meltdown. Crime, Law and Social Change 61(1): 1-13.

Punch M (2000) Suite violence: Why managers murder and corporations kill. Crime, Law and Social Change 33(3): 243-280.

Sutherland E (1949) White-Collar Crime. New York: Dryden Press.

Van Erp J, Huisman W and Vande Walle G (eds) (2015) The Routledge Handbook of White-Collar and Corporate Crime in Europe. Abingdon: Routledge.

Van Rooij B and Fine A (2018) Toxic corporate culture: Assessing organizational processes of deviancy. Administrative Sciences 8(3): 1-38.

Vogel D (2012) The Politics of Precaution: Regulating Health, Safety and Environmental Risks in Europe and the United States. Princeton, NJ: Princeton University Press.

Whyte D (2014) Regimes of permission and state-corporate crime. State Crime Journal 3(2): 237-246. 